\title{
SHARI'A, INDIGENOUS WISDOM AND HUMAN RIGHTS A Brief Review of Human Rights Enforcement in the Context of Indonesian History
}

\author{
JM. Muslimin \\ UIN Syarif Hidayatullah, Jakarta - Indonesia | pisbar2000@yahoo.com
}

\begin{abstract}
This article deals with the analysis of how human rights discourses have been articulated in the landscape of Indonesia's history. The paper argues that the idea of Shari'aization can undermine the search for the common ground in building the discourses of human rights. The history of Indonesia can be classified into three eras: precolonial, post-colonial and reform era. Along the history, the spirit of human rights enforcement grows from, and interacts with, Islam and local culture. The language and expression take various forms in accordance with sociocultural contexts and challenges. However, the essence of the enforcement is rooted in the universal values: freedom from oppression, fear, discrimination and gender inequality. In the future, smart dialogue, sharp debate and sincere discussion between 'local' symbolic expression and universal standardization are still needed. In addition, the gap can be narrowed also by responding actual violation of human right as it is indicated by Indonesian history: history of social consensus.
\end{abstract}

Keywords: Colonialism, human rights, VOC, domestic violence.

\section{Introduction}

Indonesia is a part of the human world where human rights are always endeavored to uphold and enforce. Obstacles and challenges will always be there. Nevertheless defenders of human rights in the past and up to the present have assured that the constant efforts, 
progress for the advancement of human rights enforcement can be achieved.

Since human rights values are universal, the history of human rights enforcement does not recognized boundaries of race, class, gender, religion and territory. Put differently, where there are human right violations, there will be surely one who seeks to fight against it. Example of such thing is clear: the history of Indonesia's struggle for independence is a direct part of the process and human rights enforcement efforts against the tyranny of the colonial government.

Effective enforcement of human rights requires management of visionary movement and consistent effort. The attempts to enforce human rights are often faced with cultural, legal and structural resistance. Casually, between restriction and freedom there is a space in which the demands of human rights enforcement can continue to be expressed so that space becomes increasingly widespread, loose and more freely.

This article seeks to analyse the discourses of how human rights in the history of Indonesia. This article will be broken down into the following parts; an historical context of the human rights discourses following the Indonesia's independence, followed by the human rights discourses from independence period until the New Order regime, and it will be ended by an analysis of paradoxes in the discourses in relation to Shari'a issues developed in Indonesia. The paper argues, among others, that the idea of Shariaization can undermine the search for the common ground in building the discourses of human rights.

\section{Historical Context}

In the Western world, during the Middle Ages, the power of a king is always associated with the mandate of divinity, so that the king can have absolute power to carry out the mandate power. But then the question arises when Pope Gregory VII in Dicattus Papae (1075 AD) that the highest power of divinity exists in the church while the king's power is limited to mere temporal power. Since then the king began to lose theistic-legitimacy over power.

In the course of subsequent history arises the question "where" and "on the basis of what" the king was in power. Then, popular sovereignty (vox populi vox Dei) began to appear. It was matured with the theory of social contract: the fundamental emphasis of some theories and historical experiences are the importance of the people's role and guarantee of the sovereignty and independence as individuals 
in interaction with power as well as fellow human beings. From philosophical terms, these ideas cannot be separated from the various ideas put forward by John Locke (1632-1714) and JJ Rousseau (17121778).

History later noted that the formalization of the people's rights before the authorities even spared. In England, dated June 15th 1215, the nobility (barons) rebelled against King John and gave birth to "the Great Charter" (Magna Carta). Among the main content is the king of the Great Charter must not violate property rights and personal freedoms of one of the people.

In 1628, guarantee for the independence and freedom of individuals moved forward. The Bill of Rights document was released which contains confirmation of the power of the king and the removal of restrictions on the rights of the king to exercise power against anyone, or to imprison, torture, and send troops to anyone without a legal basis.

On July 6, 1776, a milestone of history of freedom and independence of the individual was more progressive. It was characterized by the Declaration of Independence which states that: "We hold reviews these truths to be self-evident, that all men are created equal, that they are endowed by reviews their Creator with certain unalienable rights, that among these are life, liberty, and the pursuit of happiness ..."

The French Revolution (August 4, 1789) gave birth to a statement confirming the milestone of freedom and independence. Freedom and independence were focused to the five key areas: rights of property ownership (property), freedom (liberty), equation (equality), safety (security) and resistance to oppression (resistance against oppression).

In 1941, US president Franklin Delano Roosevelt (1882-1945) delivered a speech which emphasized the four fundamental freedoms, namely freedom of speech and expression (freedom of speech), freedom of religion (freedom of religion), freedom from fear (freedom from fear) and freedom from poverty (freedom from want).

On December 10, 1948 the formula of the French Revolution declaration became more reinforced by the Universal Declaration On Human Rights (The Universal Declaration of Human Rights/UDHR). This declaration includes the main points about freedom, equality, property ownership, rights in marriage, education, labor rights and religious freedom. 
Some declarations were followed by various agreements (covenants) which further expand the scope of the basic rights, among others; International Covenant on Economics, Social and Cultural Rights and the International Covenant on Civil and Political Rights in 1966. Followed by compiling the integration of various kinds of rights; economic, social, cultural, political and legal that is called the Rights of Development.

Today, the modern conception of Human Rights is predominantly derived from the context of the experience and the human tragedies that occurred in the Western world: especially Western Europe and the United States.

However, it does not mean that the rest of the world in which countries are commonly referred to as developing nations (third world) do not have the potential of cultural and historical roots that can be that deserve to be recorded as part of the universal human rights.

Paradoxically with what was happening in Europe in the $18^{\text {th }}$ to $19^{\text {th }}$ centuries, which was known as the home of the movement against tyrants and oppressors of Human Rights (HAM), even in the third world, the most dominant players and systematic human rights violators are the Europeans themselves. On behalf of the trading activity, gradually trade caravans of Europe became colonialists who wanted to make as much profit as possible in various ways that neglected the dignity of human being.

\section{Human Rights, the National Self-Esteem and Indonesian-ness; from Local Resistance towards Independence}

Broadly speaking, periodization of the human rights struggle in Indonesia can be classified into three stages: First, the phase of physical-heroic struggle that lasted for more than three centuries, from $16^{\text {th }}$ to $18^{\text {th }}$ century. At this time there were a series of physical resistance in various regions against arbitrariness and the systematic defamation of humanity, especially those carried out by merchants and the Portuguese as well as Dutch colonialists. Secondly, the phase of the ideological and organizational struggle that lasted from the beginning of the $1^{\text {th }}$ century until the independence of Indonesia (1945). At this moment, the theme of the struggle to uphold human rights in line with the ongoing maturation of the vitality of Indonesian nationalism and organizing the resistance movement and nationality; Third, the programmatic-systematic phase. At this time the enforcement of 
human rights is interpreted as a manifestation of a consensus that was based on the spirit of independence, democracy and constitutionalism.

\section{Era of Physical-heroic struggle: Islam as a significant articulator of Liberation}

In a state of bankruptcy and the continuous need for financial resources, trade colonialist models of Dutch through the Vereenigde Oostindische Compagnie (VOC) changed drastically into military and political colonialism: exploitation of the colonies grew increasingly rampant, arbitrary and inhuman actions (like taxing farmers and workers) become an easy way to reach the target of covering financial need for the Netherlands.

Forced Cultivation and distribution of the percentage (cultuur procenten) of the crops was a way then taken by the Dutch. In some cases, the whole land in a village should be planted as desired by colonial government; thousands of laborers were not paid; farmers are often moved from one place to another in vain; personnel squeezed labor for road construction work, irrigation, process of manufacture; the basic rights of indigenous people, farmers, workers had never been a concern. ${ }^{1}$

In the district of Simpur, Priangan, all men from several villages were deployed for 7 months for planting indigo far from their home. In the same place, there were 5,000 men with 3,000 buffalos for 5 months of being forced to reclaim the land for the plant. As many as 34,000 families in Rembang for 8 months were forced to work continuously with no salaries. Something similar took place in various places.

As a result: there was a famine in Demak (1848) and Grobogan (1849), infectious diseases spread drastically and mass mortality occurred. While the colonial administration: during the period of 18411863 earned a profit of 461 million guilders. Various Dutch debt can be paid off, the shipping industry and trade in Amsterdam increased. Amsterdam became the center of trade in agricultural tropical products.

\footnotetext{
${ }^{1}$ See D.W. Weldern-Rengers, The Failure of a Liberal Colonial Policy; Netherlands East Indies, 1816-1830 (The Hague: n.p., 1974), pp. 132-162; Clive Day, The Policy and Administration of the Dutch in Java (New York: Cornell Univ. Press, 1904), pp. 249-250; J.E. Stokvis, Van Wingewest naar Zelfbestuur in Nederlandsch-Indie (Amsterdam: n.p., 1912), pp. 88-95.
} 
Such conditions cannot be allowed. The struggle and the resistance to remove racist exploitation, restore the rights of indigenous, farmers and workers inflamed and spearheaded by some community leaders in the archipelago: scholars, princes and tribal leaders.

Until the end of the nineteenth century the method of struggle was dominated by frontal and heroic physical confrontations. To mention a few: the struggle of the workers in Cirebon (1816), the struggle and liberation from racism and economic exploitation by the war in Banten (1802-1806), Diponegoro War (1825-1830), Padri War (1821-1838) and the War in Aceh (1872-1908).

Wherever, in each phase of the struggle required a minimum of three things: 1) themes and common issues that could be relied upon for the liberation movement together; 2) articulator and instrumental cases that could serve to convey the message and delivery contexts, and; 3) solidarity maker which was usually manifested in the charismatic leader.

The struggle for human rights in this era was characterized by the theme of the elimination of racist treatment, economic exploitation and expulsion of foreign colonial powers. Media articulation and cases to the theme of the struggle usually began with land disputes and conflict management, neglect of the rights of local (indigenous) and racist treatment of the laborers, peasants to aristocrats. ${ }^{2}$ Articulators and spokesman of the struggle were dominated by clerics or nobles with heroic-symbolic slogan themed Islamic struggle against colonialist aggressors and non-Muslims. ${ }^{3}$

For example, in Aceh, the struggle against colonial oppression, had many symbols loaded with Islamic nomenclature. At one time (1885) when the Dutch was in a position being cornered, Tengku Cik Di Tiro, rekindle the spirit of his followers:

"For us, His creation, no movement, no peace, no life, no death, no honor, no humiliation, no victory and no defeat except by the power of God ... Thus, these unbelievers can be defeated according to God's promise". ${ }^{4}$

\footnotetext{
${ }^{2}$ J.O.M., Broek, Economic Development of the Netherlands Indies (New York: Cornell Univ. Press, 1942).

${ }^{3}$ See Anthony Reid, Sejarah Modern Awal Asia Tenggara (Jakarta: LP3ES, 2004), pp. 336339.

${ }^{4}$ Ibid., p. 335.
} 
In this case, Harry J Benda describes;

"Although it is 'impure' and despite compromises with the habits of the pre-Islamic, for the people of Indonesia, Islam serves as the focal point of identity, to symbolize the separation from and opposition to the rulers of foreign Christians. For four centuries, the resistance against the Dutch government, whether led by those who are religious fanatics or - less frequently but more feared - by Indonesian princes who fly the banner of the crescent moon, almost by itself nothing to do with Islam". ${ }^{5}$

\section{Era of Ideological-organizational movement: Plurality of Nationalist Elements}

The geopolitical map of Europe which complicated the Netherlands, the shadow of economic recession and the debate about the need for a new footing for the functioning of the colonies in the Dutch parliament before the beginning of the twentieth century led to the birth of colonial policies that seemed to be softer, friendlier and ethical.

The policy shift was also triggered by the resistance and the hard struggle of indigenous peoples to face all kinds of oppression and racist exploitation. This gave rise to a relationship that was always tense, hostile. The evil of the old political and economic policies, forced cultivation practices also lead to oppression and exploitation of the population Indies. As a result, the state of the natives was becoming increasingly versatile, backward, filled with poverty, disease, ignorance and mental degradation. The indigenous population in the state was not at all developing proficiency and skills. There was no capital, so that the production process remains just as laborers or wage worker. ${ }^{6}$

The new colonial policy line was first delivered by van Dedem as MPs. In 1891 he expressed the need for financial separation of the Dutch East Indies from the home country (the Netherlands). He also

\footnotetext{
${ }^{5}$ See and compare Harry J. Benda, Bulan Sabit dan Matahari Terbit (Jakarta: Pustaka Jaya, 1958).

${ }^{6}$ For an explanation of some of the statements of politicians ethical political orientation, see: P. Brooshooft, De Etische Koers in de Kolniale Politiek (Amsterdam: de bussy, 1901); see also, J.E. Stokvis, "Goede Worden zonder Geld," in De Taak, 1918, p. 413; Algemeen Landbouw Weekblad, 1928, pp. 1316-1317.
} 
proposed that the Dutch government needs to further enhance the development of transport infrastructure, education, health.

This idea was forwarded by van Kol, van Deventer, Kielstra and D. Fock. Van Kol became a spokesman for the socialist wing. With his experience in Indonesia he saw a variety of deterioration in many facets of life. For van Kol, indeed the Netherlands has been indebted to Indonesia because it has been so long dredge wealth. According to van Kol, labor laws, land, mining are among the tool to perpetuate the backwardness.

Van Deventer strongly criticized the Dutch government's policy that did not separate country finances from the colonized countries. He stated that during the period 1867-1878, from surplus tax (batig slot) only the Dutch East Indies has donated 187 million guilders. Similarly, Kielstra stated that since 1816, the Dutch debt (the home country) to the Dutch East Indies reached 832 million guilders. All of it is called a 'debt of honor', because if it was prosecuted, the Dutch economy itself would not be able to pay it.

Fock maintained that better education would strengthen the natives in administration. He also suggested that the expansion of irrigation, railways, lending credits to agriculture and encouraging the growth of industries based on agricultural conditions.

Including into the ranks of defenders of the need for ethical politics also was C. Snouck Hurgronje. He proposed the review of the policy related to the colonial administration of Islam in Indonesia. For Hurgronje, the colonial government needed to focus its attention on Islam, because the majority of Indonesian people are Muslim and Islam during the history of colonialism became an ideology of a great social force in stimulating resistance.

Since his arrival in Indonesia in 1889, Hurgronje recommended that the colonial government give special focus on Islam. It must be able to separate between political Islam and theological Islam. Against political Islam, the governments had to be cautious, but against spiritual Islam, the government needs to act more freely.

To Islam in Indonesia, Hurgronje also argued that the domestication of Islam would be conducted by way of a gradual political association. The point was to advance the level of knowledge and education (particularly among the nobility) and to introduce widest Western culture. That way, slowly but surely, there would be the association: indigenous aristocracy educated elite with Western 
patterns would feel the need to be part of Western civilization. Strategically, they could also play a role as a "cultural broker" which would serve as an intermediary between the masses and the western culture. ${ }^{7}$ In the atmosphere of the mind and the dominant political constellation, the national movement (eg, SI, Indische Sociaal Demokratische Vereniging/ISDV/Indonesian Communist Party and the National Party of Indonesia) for resistance and struggle to eliminate discrimination, exploitation and colonization run.

Distinctively, different from previous struggles, in this period (early twentieth century), the direction and model of the struggle had been taking a modern approach by relying on organizational managerial competence to a resistance movement. Organizational approach was reinforced with continuous efforts undertaken contextually to expand the corridor of negotiations with the freedom of colonial authority: colonial authorities felt they had rights and political permissions for a newly established organization.

Regardless of SI (Sjarekat Islam), sociologically SI could be considered as a development of primary embryo in Indonesian national resistance movement that was culturally and politically sturdy. The main characters were not purely Java-centric, but also crosscultural and ethnically diverse. SI contained in the legendary leader, Haji Oemar Said (HOS) Cokroaminoto who came from the Javanese aristocracy. There were also Haji Agus Salim and Abdel Muis, two people came from Minangkabau. In fact, in the course of its history, SI had figures who were the moving spirit of the Indonesian Communist Party (PKI) in the future, such as Semaun and Darsono. Within SI assembled some individuals and cultural observers that would be able to work together; indigenous entrepreneurs, organization administrators, scholars, cultural, urban-rural, educated-lay, and social activist. Not surprisingly, some members of Boedi Oetomo were disappointed with the attitude of their organization's tendency that was increasingly conservative and elitist, then they decided to get out of Boedi Oetomo and joined the SI. ${ }^{8}$

\footnotetext{
7 Benda, Bulan Sabit, pp. 27-52.

${ }^{8}$ See and compare: A.K. Pringgodigdo, Sedjarab Pergerakan Rakjat Indonesia (Djakarta: Penerbit Pustaka Rakjat, 1964), p. 15; Iwa K. Sumantri, Sedjarah Revolusi Indonesia, djilid 1 (Djakarta: n.p., 1963), p. 39, and p. 62.
} 
Therefore, it seems appropriate to argue that SI occupies a strategic place, unique and complex in history and national struggle to uphold human rights, against the tyranny of the colonial Dutch. Ideologically, it preceded programmatic nationalism, as in Indonesia independence slogans or manifesto development. In Islam it also preceded the renewal of Islamic standard formula in the socio-political expression of progressive theology. Its protests were forcefully threatening the status quo of colonial oppression, its expressive aspirations in economic and social fields as well as demands and consistent to the process of autonomy, freedom of the individual and society that were increasingly expanded, incorporating the aspirations to the political, national and Islamic agenda that were increasingly authoritative, calculated and typically Indonesian.

In 1916-1921, SI was known for its conviction and attitude of the organization and its resolute leaders in defending the interests of the natives, demanding legal parallels between the Dutch and the natives, rejecting attitude of humiliation, abuse and exploitation against farmers and indigenous laborers. ${ }^{9}$

In the first national congress of the SI in Bandung in 1916, Tjokroaminoto stated:

"It is not reasonable to see Indonesia as a cash cow that is fed only for its milk. It is not appropriate to regard this country as a place where people come with the intention of taking the result, and at this time is not-longer justifiable that the population, especially the indigenous population, do not have the right to participate in political issues, concerning their own fate ... we can no longer happen that someone passes the laws and regulations to us without our participation"10

In addition to fighting in extra-parliamentary forums, with tacticalstrategic considerations, SI also voiced the struggle to eliminate racial discrimination and people's rights in the Volksraad. Volksraad itself was opened on May 18, 1918, as a sort of forum of House of Representatives with very limited functions. Although Volksraad was designed as a continuation of the policy of ethical and political

\footnotetext{
${ }_{9}^{9}$ Deliar Noer, Gerakan Moderen Islam di Indonesia, 1900-1942 (Jakarta: LP3ES, 1980), pp. 114-169.

${ }^{10}$ Ibid., p. 126.
} 
inclusion controlled by the Dutch, but Tjokroaminoto and Abdoel Muis could utilize this institution with relative maximum benefit so that later on the colonial government felt necessary to discuss more carefully in this Volksraad.

The advent of Marxist labor leader H.J.F.M. Sneevliet to Indonesia in the period before World War I created new colors of struggle against colonial tyranny. In 1914 Sneevliet founded the organization Sociaal Democratische Vereniging (ISDV) which would be the forerunner of the Indonesian Communist Party (PKI). ${ }^{11}$

After seeing the social reality and the structure of Indonesian society and the development of ISDV from time to time, to develop ISDV become larger, Sneevliet decided to recruit young leaders and SI cadres as the driving force in the future.

With the technique of disguise and intelligence infiltration, finally Semaun and Darsono were successful as prospective young leaders who would be frontal, radical and non-cooperative in the effort to eliminate the colonial exploitation and overthrow the government as well. The Success of Bolshevik Revolution in Russia and the belief in increasing influence and larger number of ISDV members encouraged Semaun and Darsono to perform a similar revolution in Indonesia (1917).

In alliance with Boedi Oetomo, SI and other socio-political forces was active in organizing ISDV demonstrations and social protests, not least demand for a radical change of Volksraad. Not infrequently, too, ISDV advocated a massive organized protest for the general populace. Governor General L. Stirum welcomed the call by promising improvement. However, it turned out to be just a temporary tactic. Furthermore, when the state had been able to master, then the figures involved, including Darsono, Abdoel Muis and Sneevliet were arrested and expelled and sent back to the Netherlands.

Semaun's and Darsono's struggle did not stop. Having finished serving his sentence, in December 1920, he instead founded the Communist Party of Indonesia (CPI/PKI). Darsono and Semaun were as the chairman and deputy chairman respectively. Both were also increasingly active in diplomacy and international network initiated by the international Communist Party of Russia.

\footnotetext{
${ }^{11}$ See, Ruth Mc. Vey, The Rise of Indonesian Communism (Ithaca, N.Y: Cornell University Press, 1965).
} 
In 1924 the CPI had begun to gain widespread sympathy. Young Front League and the People as the rival of SI had been formed. At that time, in carrying out the struggle, at least PKI took two strategies: a). training and mobilizing peasants and workers as an essential element representing proletarian society; $b$. not frontally face the Islamic forces, but trying to forge tactical alliances, although it was difficult when dealing with SI. ${ }^{12}$

After feeling confident again that the cadres and social situation were ready to support the revolution, then on 13 November 1926 PKI launched social protest, resistance and open rebellion to the Dutch colonial government in Jakarta. Following that event were bloody clashes that occurred in some areas in East Java, Central and West. In a short time, the revolt could be controlled. Thousands involved were intimidated, imprisoned or exiled to Tanah Merah, Digul and Irian Jaya by the colonial administration.

PKI's history in the subsequent colonial period was shrinking. Under the strict control of the Netherlands (banned in 1927), PKI could no longer move freely. Nevertheless, later on PKI had its own political vehicle called Indonesian People's Movement (Gerindo) with Amir Syarifuddin as the central figure. SI's inspiration and noncooperative resistance movement and radical PKI later inspired some youth to continue to build the movement to eliminate the exploitation of colonialism.

Through intensive contacts between youth movements in Indonesia and overseas student associations (Association of Indonesia), then between the years 1926 to 1928 there was a time of maturation for the growth of the Indonesian National Party (PNI). Encouraged by Sukarno, PNI was founded fighting for independence against colonial tyranny. PNI combined the three ideological forces: Islam, Marxism and nationalism. In practice then, PNI program was a combination of a political program that was inciting the awareness of the oppression of the Indonesian people, giving courses in technical skills and mobilizing social movements, managerial skills and leadership. ${ }^{13}$

\footnotetext{
12 Compare with Noer, Gerakan Moderen Islam, pp. 114-169.

${ }^{13}$ Further more see, Bernard Dahm, Soekarnos Kampt um Indonesiens Unabhangigkeit, Werdegang und Ideen eines asiatischen Nationalisten (Berlin: Humboldt Univ., 1966).
} 
Year 1928 was also marked by the determination of all young country youths, PNI and the Association of Indonesia in cooperation with several local youth organizations agreed to foster a spirit of: one country, one nation and Indonesian. Soekarno was sure that what he initiated the establishment of PNI would be able to step over the previous movement in the fight for justice, eliminate discrimination and racial superiority and even towards Indonesia's independence. In one of the main speech he stated:

"It has now become clear that the national movement in Indonesia is not founded by intellectuals and communists alone, but is a common reaction of colonized people whose hearts are already independent. Indonesian revolution is the revolution today, not revolution of small groups of intellectuals, but the revolution of the biggest part of the people of the world who are left backward and fooled"14

PNI's forthright courage to achieve the ideals of Indonesia's independence and to refuse political co-operative with the Dutch and offered 'umbrella' ideology unifying the indigenous ultimately accelerated the prestige and popularity of this organization in various corners. On the other hand, it created anxiety and concern among colonial officials. The years of 1929-1930 were tough and hard for PNI. Those years were filled with shakedown events, prevention, dissolution of the meetings and the arrest of several prominent PNI's figures, including Sukarno himself.

Organizationally, PNI then became weak and continued to be weak. But the spirit of liberation from the shackles of colonial racism and the exploitation proved never extinguished in the minds of the natives. Until 1945, various events and actions to echo this spirit continued to occur: There was one of the cooperative wing party, such as petitions Soetarjo in Volksraad who wanted extensive autonomy for the Dutch East Indies; there was a merger of various movements and political parties of various schools and ideologies (Association of Indonesian Politics -GAPI).

The period leading up to independence, Indonesia was in the hands of the fascist-militaristic power of Japan. Facing japanese exploitation and atrocities carried out by its army, national figures remained adamant and tirelessly fighting the vile inhumane practices:

${ }^{14}$ For more details, see: Soeloeb Indonesia Moeda, April, 1928, no. 5, p. 119-112. 
from sex slavery to the manipulation of political persuasion to forget the ideals of independence for Indonesia.

\section{Independence from Exploitation: Towards Consensus, Lega- lization and Action}

\section{From Independence until the early New Order}

When Hiroshima and Nagasaki were bombed, the leaders of the Indonesian movement consolidated and determined to declare the freedom of Indonesia from the shackles of racial oppression and physical as well as psychological exploitation, both from the Netherlands and Japan who came afterwards. On behalf of the entire people of Indonesia, eventually declaration of independence was read by Soekarno-Hatta, on August 17, 1945.

As evidenced by the history of the nationalist movement in Indonesia, that although Islam, as has been mentioned above played an important role in the process of national integration, in its development the ideological roots of the spirit of anti-imperialism was developed and crystallized into three basic elements; Islam, nationalism and Marxism / socialism. ${ }^{15}$

The defenders of Islamic ideologies aspired to the realization of Indonesia into a state based on Islam. At the same time, defenders of nationalism and socialism hoped the same position for their ideology. In dialectic and further debate, this antagonism map then crystallized into defenders of Islamism and secularism: the Islamists insisted on Islamism while the other two groups stood on the logic of secularism. Thus, in such polarization, it would not be surprising if before and after Indonesia became independent, the debate about the fundamental pillars of statehood and nationality, as the basis of the state, human rights, was also dominated by the theme and the spirit of Islamism and secularism. ${ }^{16}$ The spirit of unity that was still felt, finally bringing the point of common agreement to accept Pancasila (compromised formula) as the state foundation and at the same time

\footnotetext{
${ }^{15}$ Robert van Neil, The Emergence of the Modern Indonesian Elite (The Hague and Bandung; W. van Hoeve, 1960); A.K. Pringgodigdo, Sejarah Pergerakan Rakjat Indonesia (Jakarta; Pustaka Rakyat, 1950); Ruth Mc Vey, The Comintern and the Rise of Indonesian Communism (Ithaca; Cornell University Press, 1961).

${ }^{16}$ For more details, see: Bachtiar Effendi, Islam dan Negara: Transformasi Pemikiran dan Praktik Politik Islam di Indonesia (Jakarta: Paramadina, 1998).
} 
the main legal reference source. Then, on 18 August 1945 by the Working Committee of KNIP, 1945, in which Pancasila was stated as the foundation of the state, applied. Milestones of consensus and this constitution is the starting point of reference enactment of legal rights de facto and de jure.

The opening of 1945 Constitution itself begins with a statement of commitment to human rights: that independence is the right of all nations, then the occupation over the world should be abolished, because it does not comply with humanity and justice. Also in later chapters on the state and the nation's commitment to the rights of association, assembly and expression is regulated.

However, the running of the government after independence is not yet stable. Netherlands still did not want the independence of Indonesia. There were aggressions I and II launched with the intent of recapturing Indonesia. There was an internal social protests carried out by the Indonesian Communist Party (PKI). Through physical guerrilla warfare, internal consolidation and international diplomacy, ultimately the Netherlands and Indonesia met again to establish an agreement thread made Indonesia as the Federal Republic of Indonesia (RIS), the RIS Constitution.

Seen from the perspective of human rights, compared with Constitution of 1945, the RIS Constitution was later modified in accordance with the political setting into the 1950 Constitution (temporary Constitution), is a law that is more appreciative of human rights enforcement. There are more details about the rules and state guarantees for the enforcement and protection of human rights: freedom of association, assembly and expression are more scalable and not solely limited by the interpretation and the power of the state.

Unfortunately, the Constitution was not getting a decent place to survive. Skills for organizing a state, readiness, cultural experience of citizens and state officials to manage an independent state have not been fully tested. The forces of civil society (political parties, civil society organizations) were actually engaged in a political power struggle protracted. Government and cabinet were ups and downs in a very short time and did not allow it to focus on the social welfare agenda. However, it was under the Provisional Constitution that the General Election was held successfully for the first time (1955).

Successful elections that took place direct, general, secret and fair and just produced legislators (the Constituent Assembly), with the 
principal task of preparing a new constitution. However, due to an acute conflict of ideas, it has not reached consensus and agreement on the new constitution. Finally, the President felt to have political legitimacy to issue a presidential decree that contained the dissolution of the Constituent Assembly and the return to the 1945 Constitution.

Until the fall of Sukarno from power, the practical interpretation of the Constitution of 1945 was done by Sukarno. On the matter of legislation, the 1945 Constitution does not restrict the president's role and much more likely to hang the fate of state and government to the president. Coupled with a centralized leadership model, then in the 1960s, Sukarno always created conditioning emergency under the pretext of "unfinished revolution". In practice, human rights protection was still minimal and had not shown progress.

Political chaos that was driven by the Indonesian Communist Party (PKI) in 1965, led to the fall of Sukarno and he was replaced by General Suharto. The Constitution of 1945 has not changed, but under the slogan "the implementation of the 1945 pure and consistent", it brought about the practice of 'Pancasila democracy': the repression to minimize political parties, economic development as the main goal, to make re-interpretation of power over the constitution as the constitution itself. The main principles of human rights, in the name of 'democracy Pancasila' were often overlooked.

\section{Era of Reformation and Human Rights}

The monetary crisis, public pressure and the neglect of human rights led to the fall of Suharto (1998). Reform mandate is one of the main demands of the country and the government's firmness commitment to human rights. The claim is then echoed by the 1945 amendment. The Constitution of 1945 is seen that it has created itself to multiple interpretations. Top unilateral interpretation of the 1945 Constitution has given the perceived negative climate for the growth of collateral and the enforcement of human rights. The authorities even often made the Constitution of 1945 as the 'shield' of power to oppress the rights of citizens.

Arrangements in Article 27, paragraphs 1 and 2 of the 1945 Constitution on the guarantee of citizens' equality before the law and guarantee of jobs and a decent living as well as article 28 on freedom of association, assembly and expression here seen as something conventional, abstract and often construed its own fit the tastes of rulers. Faced with such demands, there were at least four groups of 
opinion; first, agreed to change but did not touch opening and other crucial article; second, agreed to make absolute change: the third, unnecessary or not yet an appropriate time for a change; fourth, agreed to change but it must be done before a complete study conducted by an independent commission (Constitution Commission).

After a tough debate between the four groups, the direction of the debate led to the understanding that: a constitutional change should be understood objectively-proportionally. Changes in the Constitution did not mean eliminating the soul, sense and nuance of the unity of the nation within the Unitary State of the Republic of Indonesia (NKRI), but must be viewed realistically as the best way for the survival of the nation's future in a situation and contextual challenges. ${ }^{17}$

In keeping with these developments, there were at least four times change of a second amendment to the 1945 Constitution. Second Amendment of 1945 Constitution was focused on the themes of human rights in the constitution. This second amendment eventually included Human Rights (HAM) into a separate chapter, namely Chapter XA on Human Rights with 10 chapters (chapters 28 ABCDEFGHIJ). Contents on Human Rights (HAM) in the second amendment of the 1945 Constitution were far exceeds the provisions stipulated in the Constitution of 1945. In addition to the presence of a separate chapter on human rights, another thing is more detailed chapters which confirm personal commitment and protection of human rights and citizens'.

The commitment and guarantees of human rights protection also still remain to be found in the provisions of articles such as Article 27 paragraph 1 and 2 as well as article 28 , on equality before the law, the right to a proper life and freedom of expression and assembly. All of this chapter is the original text of the 1945 version before the amendment. ${ }^{18}$

\section{Women and Human Rights}

In addition to the physical confrontation with the Dutch, the end of the nineteenth century was also marked with the rise of Indonesian women from masculine dominating culture and patriarchal social structure of exploitation. If Nyi Ageng Serang (1752-1828), Martha

\footnotetext{
${ }^{17}$ Majda El-Nuhtaj, Hak Asasi Manusia dalam Konstitusi Indonesia (Jakarta: Kencana, 2005), p. 85 and p. 112.

18 Ibid.
} 
Christina Tiahahu (1818), Cut Nyak Dien (1850-1908) and Cut Mutia (1870-1910) were the driving spirit of heroic and wrecker of the male military leadership traditions, then Kartini (1879-1908) represented the originator of the idea and the feminist movement. The feminist ideas of Kartini does not arise spontaneously but through a series of psychological torture that happened: she was the fourth wife, betrothed to a husband who was not of her own choice, confined by the traditional masculine aristocracy and patriarchal conservative religious understanding. ${ }^{19}$

Awareness of the need for male-female equality then spread and socialized: Muhammadiyah has a women association themselves, SI and SI People also have associations of women. ${ }^{20}$ "Princess Mardika" that was founded in Jakarta in 1912 sought to strengthen and speed up women awareness of their rights: women could not be confined to domestic roles, she was able to appear in public, she had equality with men. "Princess Mardika" also started campaigning about the difference and non-natural differences. Natural differences could not be avoided, while non-natural as cultural construct, should be eliminated. This organization was not only engaged in domestic but also established and responded to feminist issues that developed internationally. ${ }^{21}$

On December 1945, the first congress of women in Indonesia was held after the war. The next year the women's organization which had grown rapidly, incorporated into the Women's Corps of Indonesia (Kowani). In its congress in 1949, Kowani managed to formulate several statements to the interests of women; a). The equal rights of men, women should be included in the constitution; b). All citizens, including women have the right to transform and work; c). Labor laws should be drafted with regard to women's interests; d). Marriage laws are codified and enforced in accordance with their respective religion.

In the early days of independence until the collapse of the old order and lively political competition between political parties made women groups subordinated to the interests of each party. Almost no

\footnotetext{
${ }^{19}$ For more details, see: Pramoedya Ananta Toer, Panggil Aku Kartini Sadja (BukittinggiDjakarta, 1962).

${ }^{20}$ Pringgodigdo, Sedjarah, p. 89.

${ }^{21}$ For more details, see: Fauzie Ridjal, et.al (ed.), Dinamika Gerakan Perempuan di Indonesia (Yogyakarta: Tiara Wacana, 1993); S. Eleonora Weiringa, Penghancuran Gerakan Perempuan di Indonesia (Jakarta: Garda Budaya, 1999).
} 
political party had a women's organization. This shows the significant role of women's organizations which were increasing on the one hand, but on the other hand shows that the ideology of women as "follow and support" the men still thrived.

In 1952 Kowani convened a congress. In this Congress Kowani passed a resolution: a). That women should actively participate and given a place in the Islamic Court; b). For some officials who dealt with family law issues are given special training; c). A special team for women's education was formed; d). The advisory board bureau should involve women as wider workforce; e). Publishing who do not heed the moral value given firm legal sanctions. ${ }^{22}$

Entering the New Order era, along with the repressive political dominance, the women's movement became increasingly cornered systematically. In all state institutions women's organization was formed under the name of Dharma Wanita. In the rural communities and villages layer formed Family Welfare Education (PKK) was formed. Unfortunately, what was done in the PKK and Dharma Wanita was more likely to perpetuate the ideology of female domestication and male supremacy. Training provided by PKK is educational skills of domestic tasks: cooking, sewing and making wreaths. While in the Dharma Wanita organization, the wives of civil servants are taught not to speak out loud, do not be selfish and put the interests of their husbands, ready to help their husbands remain to flourish.

The type of female activities of New Order is still dominant until today's era of reform. Until now, the general women's movement is still dominated by subordinating culture and male supremacy, especially those committed by non-activity and independent organization (the PKK and Dharma Wanita). On the other hand, some women's organizations are more independent led by the Institute Swadaya community and social organizations better able to respond to the challenges of the actualization and the revitalization of the equal existence and rights of women-men progressively and contextually, both at the level of concepts and management movement.

The issues associated with domestication, subordination and violence against women, in the civil, economic, social and cultural

22 See: Kowani, Sejarah Setengah Abad Pergerakan Wanita Indonesia (Jakarta: Balai Pustaka, 1978). 
realm continues to be criticized by the latter group. Among others, because of their criticism that Indonesia has ratified the UN Convention 1979 (Convention on the Elimination of Discrimination against Women), ratification of the UN convention No. 138/1973 concerning Minimum Age for Admission to Employment (Law No. 20/1999), the ratification of the UN Convention No. 111/1958 concerning Discrimination in Respect of Employment and Occupation (Law No. 21/1999), the ratification of the UN convention No. 182/1999 on the Prohibition and Immediate Action for the Elimination of the Worst Forms of Child workers and has Law No. 23/2004 on the Elimination of Domestic Violence in the household. Although the text of legislation is not a guarantee of the rights of women being protected, at least the contents of the bill show the strong determination towards that direction.

\section{Paradox Tendency; Shari'a, Human Rights, Civic Mindedness and Obedience ${ }^{23}$}

As described above Islam has played an important role along the history of Indonesian struggle for Independence (struggle for human rights enforcement and protection). Moreover, to some extends Islam had been integrated culturally with indigenous folkways. Today, such a contribution for some Muslims can be a legitimate reason to have an agenda of applying Islam totally (kaffab). The keyword of this agenda is by enforcing shari'a. The strong tendency of such an agenda is applying a lateral Islamic penal code.

The tendency of applying a lateral Islamic penal code will cause a serious socio-legal problems and paradox: from campaigning and institutionalizing gender inequality to legalizing minority discrimination in the name of Islam. Hence the role of Islam in the history of Indonesia and in the real sense has been manipulated. Thus, civil liberties as well as human dignity are in danger.

Therefore it is not mistaken to conclude that the agenda for the application of Shari'a in Indonesia is often understood as the application of Shari'a criminal law perceived as the antithesis to the

\footnotetext{
${ }^{23}$ Some ideas are extracted and modified from Troy Duster, The Legislation of Morality: Laws, Drugs, and Moral Judgement (New York: Sage Foundation, 1970), pp. 12-67; E. Bodenheimer, Jurisprudence: The Philosophy and Method of the Law (Cambridge: Harvard Univ Press, 1974); Alan Watson, The Evolution of Law (Baltimore: John Hopkins Univ. Press, 1985): pp. 45-65.
} 
core principles of Human Rights. Shari'a in this context has not been understood yet as the noble values extracted from divine principle (transcendental) which contains the teachings of liberation and humanity (humanistic values); a tenet which contains a blend of the divine vision and real human experience throughout history to find the formula of conflict resolution (values and law formulas) for continuous existence outwardly or inwardly (Al-Imran 110; al-Jatsiyah 18). This vision and mission of shari'a has been practiced contextually and very well during the era of struggle for Indonesian independence.

Knowing the serious implication, the creative minority of Indonesian Muslims should be very careful in searching a wide and comprehensive method of resolving the problems. The method can be exercised through: a. Dialogue; b. Cultural means of 'islamization'; c. Sound Legal education

\section{Dialogue}

Dialogue between shari'a and modern social reality needs to be continuously carried out. Shari'a should not be a value and a fossilized framework of understanding; Shari'a has high flexibility and creativity as had been demonstrated by thinkers throughout the ages. Like a tree, Shari'a can be grown anywhere, although the conditions of soil fertility is varying. In other words, in the context of the nation-state, such as Indonesia, Shari'a can serve as a substance of potential value to provide the roots for the growth of pure devotion (pure legal obedience) and being loyal to the constitution and existing legislation. It comes to give meaning that the life of nation and state requires a spirit, the spirit of sincerity, a sense of belonging and commitment to consensus and legal decisions together, as a continuation of their depth of full comprehension and willingness to sacrifice that grow and develop from providing religious meaning of life and original dimension of divinity.

On the relationship of such meaning, the tools and products of existing legislation are not merely a profane rule which is only eligible to be used as a cognitive reference and to play semantic understanding of legislation (Begriff und Normwissenschaft) in dispute and formal technical-juridical debate, but was born to be obeyed and used as manual based on sincerity and purity principles of obedience. Thus, through shari'a, Indonesian basically can be taught to "respect the constitution and obey the scriptures" (al-Nisa 58-59). 
The basic characteristics of obedience can be devided into three; a. forced obedience; people obey the law because the are forced to do so. They will be sentenced by hard sanction for their betrayal and refusal. Here the obedience comes from sanction and force. It is hard to be called as pure obedience; $b$. Transactional obedience; to obey the law one should know that by obeying the law, reward will come. By refusing law, punishment will exist. It is reciprocal nature of obedience; c. Trancendental obedience; obedience to the law comes from heart and theological awareness. Here, the law is regarded as a manifestation of trancendental meaning. The law exists not merely as social contract or reciprocal regulation but it has inner meaning as the need of spirituality and immaterial motivation.

In such a context and in the relation of human rights protection and law enforcement, shari'a should serve psychological basis for obedience and legal awareness. Moreover, shari'a can lead the believers to maintain and secure public interest (maslahah) by promulgating the law and emphasize its necessity for the society. The law is not only social contract but also spiritual sign of commitment.

\section{Cultural 'Islamization'}

One thing to be appreciated today in line with the beginning of the prevalence of Islamic education in various parts of the country is an understanding of Shari'a starts to improve. There is a willingness of various parties to understand, explore and practice the essence of Shari'a. In the banking and financial business sector, for example, values of Shari'a began to be extracted and applied. Related to the dignity of women and the attitude of permissiveness there has been Anti-Pornography and Porno-action Bill (UU APP), though it still has various shortcomings. In some activities (including the popular soap opera on the electronic media), people are also getting familiar with the terminology of Shari'a: there are some films entitled Ketika Cinta Bertasbih (When Love tells its beads), the Murabbi, Laskar Pelangi (Rainbow Warriors), etc. are implicitly and explicitly telling about the Indonesian people's need to always rest on community spirit (volksgeist) which is based on the nature of Shari'a.

Despite the existing shortcomings, directly or indirectly, these conditions can be predicted (slowly but surely) as an elimination process of antipathy towards Shari'a (shari'a phobia). If this situation continues, it will in turn create a welcoming atmosphere for the 
presence of "an interavtive space" between the Islamic positive law, and the present reality objectively, participatorily, and democratically.

Hence shari'a campaign should be conducted through cultural means, cultural festivities and avoiding hard and violent instruments. The principles of maqashid (maqashid al-syar'iyyah) must be put in the priority of strategic campaign. Lateral campaign of shari'a will face hard and cruel political as well as social responses. Only through cultural assimilation packaging, shari'a will contribute significantly in creating a tolerant society and it will enhance the maturity of civic mindedness and empower the cultural basis for human rights protection.

\section{Legal Education}

At least three writers can inspire us in discussing the role of education. In his famous statement, John Dewey, a famous writer and philosopher wrote: ${ }^{24}$

"Can we connect this "new education" with the general march of events?. If we can, it will lose its isolated character; it will cease to be an affair which proceeds only from the overgenius minds of pedagogues dealing with particular pupils...."

"Education is the fundamental method of social progress and reform. All reforms which rest simply upon the enactment of law, or the threatening of certain penalties, or upon changes in mechanical or outward arrangements, are transitory and futile..... Education is a regulation of the process of coming to share in the social consciousness; and that the adjustment of individual activity on the basic of this social consciousness is the only sure method of social reconstruction".

Shari'a education needs to be reconstructed in accordance with social need and relevance. Civil liberty is the issue of basic need. A serious threat toward principles will lead us to human horror. Shari'a education can empower sensitive feeling of human rights through some steps as follow:

${ }^{24}$ Reginal D. Archambauld, John Dewey on Education: Selected Writings (New York: The Modern Library, 1964), p. 296. 


\section{Stages of Cognitive Development}

Knowing justice and human rights as the soul of law, educational institution should introduce the principles from the early steps of learning shari'a. In order to understand the principles properly, the teachers begin teaching shari'a with some introductory courses on shari'a and its principles of justice human rights in the real and comparative fashion. The materials are further equipped by getting to the deeper substance of specific issues in specified materials of law, such as law of war, Anti-corruption Law, law of refugees, etc. The teaching of specified materials is grounded by analytical process of "General Concept of Shari'a and Its principles". In this stage (for example) the Stufenbau Theorie of Hans Kelsen and Volksgeist Theorie of Karl Friedrich von Savigny is blended, introduced and it plays a role as a tool of building analyses.

After introducing the preliminary understanding of shari'a and those issues, the specification and basic general philosophy and theories, the students are given the opportunity to have a deep understanding of how can the shari'a blended with the law enforced. Then they begin learning the law of procedure, its principles and problems. Before ending their study, every student has to do a general test called "a comprehensive test". The test tries to resume and summarize that studying shari'a and the issues must be in a comprehensive manner: from its basic theories as fundamental foundation to the materials, process and procedure and its practice as a legal solution, a legal comparison, analyses and social commitment.

\section{Stages of Justice Reasoning and Moral Judgment}

Shari'a and those issues studied are not only a set of materials and lessons to be remembered and reproduced. But it is a set of moral massages, norms and values. Knowing and understanding this postulate, the educational institution try to teach shari'a and the law by creating innovative approach: strengthening cognition but empowering it by building case study method. Case study method enables students to have an opportunity for seeing the cases in its multidimensional perspectives.

To keep the students enthusiastic in learning and sharpening their legal skills by case study method, the facilitators select the cases to be always actual, relevant and attracting public attention. The actual case will lead the students to find a new dimension and variety of cases. Whereas, the relevant cases cause the students to think correlatively 
with the material law and law of procedure. Attractive cases which take public attention will drive students to think carefully. The students feel bounded to the cases because their solution of cases can influence public awareness, support as well as protest. Unless they find valid and strong legal logic and argument, their legal opinion will be tested publicly as weak, unvalid, unlogic and injust.

Justice Ideals, Human Rights Protection, Practical Involvement and Moral Responsibility

As it is mentioned above, learning shari'a and those legal issues is mastery on the system of cognition and on skill at the same time. While shari'a and the law interact directly with society, then the students of law should not see the law from above but they have to involve within society to find legal solutions for cases existing in society.

Finding legal solution can be trained by empowering the system of cognition. Curriculum, syllabus, learning tactics and environment will assist to achieve the goal of learning. In the stage of human rights sense and feeling, justice reasoning and moral judgement, students' legal skills are sharpened and their moral commitments to justice are tested. Therefore, the students are trained to be used to think logically and judge intuitively.

In the stages of practical involvement and moral responsibility, the students are simulating themselves in the mid of society. They are not only challenged by logical thinking but also questioned by their moral commitment to anti-corruption and justice. At this level, students see, think, involve in activities to use the law as a tool of social engineering, social cohesion, social harmony and social control.

Automatically, at this level, the students try to think about the law and its enforcement from 'out of box' side: how to make law effective socially, how to integrate legal skills in empowering society within the framework of local wisdom, how to reform cultural basis of society to cope with many models and practices of corruption without neglecting people's cultural roots.

In short, by the students' direct involvement in society, they feel moral responsibility to contribute their legal skills. They can see also that justice ideals are contextual. But the sense of anti-corruption and justice has to be in every legal solution. Students' justice sensitivity must be kept and improved. It is immaterial and moral commitment 
for everyone. It cannot be bartered by anything. It is a moment of balancing between cognition and moral responsibility.

Stages of cognitive development, justice reasoning and moral judgement are strengthened by stages of justice ideals and human rights, practical involvement and moral responsibility. By such a process, students will conclude that learning law is actual and empiric. Justice ideals and human-rights are living, colouring and existing in everyone's life. The obstruction of justice and human rights are immoral act.

\section{Conclusion}

The struggle for human rights in Indonesia cannot be separated from efforts of various community groups to eliminate the foreign occupation. It is seen as the root of major human rights violations and defamation. At first, the dominant inspiration of anti-exploitation resistance is exhaled by Islam, then coupled with Marxist-socialism and its peak is more reinforced by the language of nationalism.

The efforts to eliminate colonization were carried out by means of physical-heroic, organizational-tactical. Meanwhile, the human right enforcement efforts in the future of independent Indonesia are carried out by building on national life which characterizes the principle of democratic constitutionalism: the legalization of human rights protection in the Constitution based on the aspirations and people's participation.

In terms of legal-constitutional, human right protection experienced ups and downs according to the context of the political, social, legal culture. In the early days of independence, there was a strong effort to draw up the Constitution in accordance with the spirit and tradition of liberal politics (UUD 1950/Provisional Constitution). Along with the resignation of the country's commitment to fight for human rights and the increasingly low capacity of government executors to actualize the welfare, then president Sukarno and Suharto did not make protection of human rights as a priority agenda. Moreover, the 1945 Constitution before its amendment has only a few offensive addressed explicitly on human rights.

Until now there are at least two strong tendencies of the women's movement: the subordinate-patriarchal ideology promoting the idea of relative equality, the other group promotes the ideology of absolute equality anti patriarchy. As a result of the reform and apart from various shortcomings, there was a constitutional amendment. Along 
with the amendment, legal commitment to upholding and protecting human rights, including gender equality, are becoming increasingly progressive.

The agenda of applying shari'a can be a paradox and regressive way of Islamizing Indonesia; threatening basic values of human rights. Terms and conditions of applying shari'a should be carefully analyzed and contextualized. If not, it will cause a permanent tension and conflict, instead of harmony and consensus.]

\section{References}

\section{Books and Articles}

Benda, Harry J. Bulan Sabit dan Matahari Terbit. Jakarta: Pustaka Jaya, 1958.

Broek, J.O.M. Economic Development of the Netherlands Indies. Ithaca-NY: Cornell Univ. Press, 1942.

Brooshooft, P. De Etische Koers in de Kolniale Politik. Amsterdam: n.p., 1901.

Dahm, Bernard. Soekarnos Kampt um Indonesiens Unabhangigkeit, Werdegang und Ideen eines asiatischen Nationalisten. Berlin: Humboldt Univ., 1966.

Day, Clive. The Policy and Administration of the Dutch in Java. NY: Cornell Univ. Press, 1904.

Effendi, Bachtiar. Islam dan Negara: Transformasi Pemikiran dan Praktik Politik Islam di Indonesia. Jakarta: Paramadina, 1998.

El-Muhtaj, Majda. Hak Asasi Manusia dalam Konstitusi Indonesia. Jakarta: Kencana, 2005.

Fauzie Ridjal, at. al. (ed.). Dinamika Gerakan Perempuan di Indonesia. Yogyakarta: Tiara Wacana, 1993.

Huijbers, Theo. Filsafat Hukum Dalam Lintasan Sejarah. Yogyakarta: Kanisius,1998.

Kowani, Sejarah Setengah Abad Pergerakan Wanita Indonesia. Jakarta: Balai Pustaka, 1978.

Locke. "Two Treaties of Government, A Letter on Toleration, An Essay Concerning Human Understanding." in Jack Lively and 
Andrew Reeve (ed.). Modern Political Theory from Hobbes to Marx: Key Debates. New York: Routledge, 1983.

Noer, Deliar. Gerakan Moderen Islam di Indonesia, 1900-1942. Jakarta: LP3ES, 1980.

Powell, Edward. Kingship, Law and Society: Criminal Justice in the Reign of Henry $V$. Oxford: Clarendon Press, 1989.

Pringgodigdo, A.K. Sedjarah Pergerakan Rakjat Indonesia. Djakarta: Penerbit Pustaka Rakjat, 1964.

Reid, Anthony. Sejarah Modern Awal Asia Tenggara. Jakarta: LP3ES, 2004.

Smith, Edward C. The Constitution of the United States. New York: Barnes \& Noble, 1966.

Stokvis, J.E. Van Wingewest naar Zelfbestuur in Nederlandsch-Indie, Amsterdam: n.p., 1912.

Toer, Pramoedya Ananta. Panggil Aku Kartini Sadja. BukittinggiDjakarta: n.p., 1962.

United Nations, Human Rights; A Compilation of International Instruments, vol. 1. New York: United Nation, 1999.

van Neil, Robert. The Emergence of the Modern Indonesian Elite. The Hague and Bandung: van Hoeve, 1972.

Vey, Ruth Mc. The Rise of Indonesian Communism. Ithaca, New York: Cornell University Press, 1965.

Weiringa, S. Eleonora. Penghancuran Gerakan Perempuan di Indonesia. Jakarta: Garda Budaya, 1999.

Weldern-Rengers, D.W. The Failure of a Liberal Colonial Policy, Netherlands East Indies, 1816-1830. The Hague: n.p., 1974.

Zainuddin, A. Rahman. Hak-hak Asasi Manusia: Sebuab Bunga Rampai. Jakarta: Obor, 1994. 